Copyright by the American Society of Agricultural and Biological Engineers. Soupir, M. L.; Mostaghimi, S.; Lou, J., "Die-off of E. coli and enterococci in dairy cowpats," Transactions of the ASABE. 51(6): 1987-1996. (doi: 10.13031/2013.25403)@2008

\title{
Die-OfF of E. COLI AND ENTEROCOCCI IN DAIRY COWPATS
}

\author{
M. L. Soupir, S. Mostaghimi, J. Lou
}

\begin{abstract}
E. coli and enterococci re-growth and decay patterns in cowpats applied to pasturelands were monitored during the spring, summer, fall, and winter. First-order approximations were used to determine die-off rate coefficients and decimal reduction times (D-values). Higher-order approximations and weather parameters were evaluated by multiple regression analysis to identify environmental parameters impacting in-field $\mathrm{E}$. coli and enterococci decay. First-order kinetics approximated $\mathrm{E}$. coli and enterococci decay rates with regression coefficients ranging from 0.70 to 0.90 . Die-off rate constants were greatest in cowpats applied to pasture during late winter and monitored into summer months for E. coli $\left(k=0.0995 d^{-1}\right)$ and applied to the field during the summer and monitored until December for enterococci $\left(k=0.0978 d^{-1}\right)$. Decay rates were lowest in cowpats applied to the pasture during the fall and monitored over the winter $\left(k=0.0581 d^{-1}\right.$ for $\mathrm{E}$. coli, and $k=$ $0.0557 d^{-1}$ for enterococci). Higher-order approximations and the addition of weather variables improved regression coefficients to values ranging from 0.82 to 0.96 . Statistically significant variables used in the models for predicting bacterial decay included temperature, solar radiation, rainfall, and relative humidity. Die-off rate coefficients previously reported in the literature are usually the result of laboratory-based studies and are generally higher than the field-based seasonal die-off rate coefficients presented here. To improve predictions of in-field $\mathrm{E}$. coli and enterococci concentrations, this study recommends that higher-order approximations and additional parameters such as weather variables are necessary to better capture re-growth and die-off trends over extended periods of time.
\end{abstract}

Keywords. Die-off, E. coli, Enterococci, TMDL, Water quality.

$\mathrm{R}$ unoff from grazed pasturelands has been well documented as a source of fecal contamination of surface waters (Doran and Linn, 1979; Doran et al., 1981; Moore et al., 1982; Soupir et al., 2006). Animal manure applied to agricultural lands is a significant source of pathogenic organisms, and it is possible that over 150 pathogens found in livestock manure could be transmitted to humans (U.S. EPA, 2003). During runoff events, pathogenic organisms can be transported to surface waters, leading to potential waterborne disease outbreaks. E. coli and enterococci are the two bacterial indicator organisms thought to have a higher degree of association with outbreaks of gastrointestional illness (U.S. EPA, 1986) and are, therefore, currently the two recommended bacterial indicator organisms (U.S. EPA, 1998, 2002).

Total Maximum Daily Load (TMDL) plans, which are heavily dependent on modeling the fate and transport of bac-

Submitted for review November 2007 as manuscript number SW 7256 approved for publication by the Soil \& Water of ASABE in October 2008. Presented at the 2007 ASABE Annual Meeting.

This publication has not been formally reviewed by the EPA. The views expressed in this document are solely those of the authors, and the EPA does not endorse any products or commercial services mentioned in this publication.

The authors are Michelle L. Soupir, ASABE Member, Assistant Professor, Department of Agricultural and Biosystems Engineering, Iowa State University, Ames, Iowa; Saied Mostaghimi, ASABE Member, H. E and Elizabeth F. Alphin Professor and Department Head, Department of Biological Systems Engineering, Virginia Tech, Blacksburg, Virginia; and Jianying Lou, Graduate Research Assistant, Department of Statistics, Virginia Tech, Blacksburg, Virginia. Corresponding author: Michelle L. Soupir, Department of Agricultural and Biosystems Engineering, 3163 NSRIC Building, Iowa State University, Ames, IA 50011; phone: 515-294-2307; fax: 515-294-4250; msoupir@iastate.edu. terial indicators, are implemented to remediate waters impaired by fecal bacteria. Accurate predictions of bacterial concentrations in sources within a watershed, such as fecal deposits or land-applied manure, are necessary for simulation of in-stream concentrations. Muirhead et al. (2005) found that a statistically significant linear relationship existed between the mean number of $E$. coli cells in cowpats and the mean number of $E$. coli cells in runoff, emphasizing the need to better model indicator concentrations in fecal sources to improve predictions of pathogen indicators transported to surface waters.

E. coli $\mathrm{O} 157: \mathrm{H} 7$ is a pathogenic strain of $E$. coli present in surface waters when feces of infected humans or animals are discharged into unprotected waterways. Ingestion of contaminated waters could result in diarrhea, vomiting, and possibly hemolytic-uremic syndrome (ASM, 2002). Vinten et al. (2002) and Mubiru et al. (2000) determined that the E. coli O157:H7 die-off rate was the same as or faster than total $E$. coli, indicating that evaluation of total $E$. coli die-off should be representative of the pathogenic strain. The three commonly observed patterns of indicator bacteria die-off are first-order decay, bacteria growth followed by first-order decay; and first-order decay with variable die-off rates (Crane and Moore, 1986; Mancini, 1978). Since little is actually known about the individual influences and interactions between the many parameters affecting die-off, first-order decay is most often used to express bacterial die-off (Crane and Moore, 1986; DeGuise et al., 1999; Moore et al., 1988; Wang et al., 2004):

$$
N_{t}=N_{o} \exp (-k t)
$$

where $N_{t}$ is the number of bacteria at time $t, N_{o}$ is the number of bacteria at time $0, k$ is the first-order die-off rate constant $\left(\right.$ day $\left.^{-1}\right)$, and $t$ is the elapsed time (day). 
Pathogens and organisms with the capabilities to form spores can survive free-living in the soil for years, but most pathogens encounter conditions that prevent normal cell functions once they leave the host. Crane et al. (1983) summarized the variables that affect the survival of enteric organisms: physical and chemical properties of the soil including $\mathrm{pH}$, porosity, organic matter content, texture and particle size distribution, elemental composition, temperature, moisture content, absorption and filtration properties, and availability of nutrients; atmospheric conditions including sunlight, humidity, precipitation, and temperature; biological interaction of organisms including competition from indigenous microflora, antibiotics, and toxic substances; the application method including the technique and frequency; and density of the organisms in the waste material. It is also known that some potential pathogens are free-living in the soil and may be nourished by animal wastes (Ellis and McCalla, 1978).

While many variables are thought to influence bacteria survival, temperature and moisture content of the soil or manure are considered to be key factors related to die-off (Himathongkham et al., 1999, Wang et al., 1996, Wang et al., 2004). Wang et al. (2004) found that temperature (but not moisture content) had a significant effect on indicator bacteria die-off in dairy cow manure. E. coli $\mathrm{O} 157: \mathrm{H} 7$ inoculated in dairy manure survived for 63 to 70 days when incubated at $5^{\circ} \mathrm{C}$ with a high (74\%) moisture content, compared to 49 to 56 days when incubated at $22^{\circ} \mathrm{C}$ and 42 to 49 days when incubated at $37^{\circ} \mathrm{C}$ with lower (10\% at the end of the study) moisture content (Wang et al., 1996). Mubiru et al. (2000) attributed variations in $E$. coli survival inoculated in two soils to differences in available water in the soil matrix. Most rapid die-off of E. coli $\mathrm{O} 157: \mathrm{H} 7$ and Salmonella typhimurium were observed at $37^{\circ} \mathrm{C}$ when compared with $4^{\circ} \mathrm{C}$ and $20^{\circ} \mathrm{C}$ in manure $(\mathrm{Hi}-$ mathongkham et al., 1999). E. coli O157:H7 inoculated in feces in the laboratory survived best when incubated at temperatures below $23^{\circ} \mathrm{C}$ but also survived for shorter periods of time than manure exposed to the external environment, emphasizing the difficulty in applying laboratory results to field conditions (Kudva et al., 1998).

Several studies have detected bacterial after-growth following land application of waste. Crane et al. (1980) applied poultry manure to bare soil plots in a controlled environment. The manure was applied at approximately 36.5 and $164 \mathrm{t} \mathrm{ha}^{-1}$ on Norfolk loamy fine sand from the coastal plains and on Davidson clay loam from the Piedmont region. Die-off of fecal coliforms was rapid immediately following the manure application until day seven. The first seven days were followed by a period of re-growth lasting five days, and then the organism concentrations remained constant. Although the regrowth could not be attributed to a single factor, the high soil moisture content and the mild unfluctuating temperature most likely contributed to the re-growth. Laboratory studies have also found increased concentrations of fecal coliforms and $E$. coli in manures for up to a week following excretion
(Conner and Kotrola, 1995; Wang et al., 1996; Wang et al., 2004).

Shortcomings have been identified with the first-order decay equations frequently used to model bacterial die-off, and the need is expressed for development of new equations to better predict the bacterial growth and die-off dynamics for extended periods of time (Wang et al., 2004). The goal of this study was to assess $E$. coli and enterococci re-growth and decay patterns in cowpats applied to pasturelands. Seasonal variations in decay patterns were assessed using the decimal reduction times ( $D$-values) and first-order decay coefficients. Higher-order approximations and weather parameters were evaluated by multiple regression analysis to identify parameters impacting in-field decay and to identify possible techniques to improve modeling of $E$. coli and enterococci fate.

\section{MATerials ANd Methods}

Freshly excreted dairy cow feces were collected from four to seven animals at the Virginia Tech dairy facility over a $24 \mathrm{~h}$ period. Freshly excreted feces were transported in barrels to the Virginia Tech Prices Fork Farm. Standard cowpats (Thelin and Gifford, 1983) were formed by mixing the feces in a cement mixer for $15 \mathrm{~min}$. The homogenized manure was placed in molds with a diameter of $20.3 \mathrm{~cm}$ (8 in.) and a depth of $2.54 \mathrm{~cm}$ (1 in.) until a weight of $0.9 \mathrm{~kg}(2.0 \mathrm{lbs})$ was reached. Approximately 100 cowpats were formed and applied to a mowed hay field. Cowpats were applied to the field in a randomly distributed pattern, but the distance between pats was less than two to three feet. During the growing season, grass was mowed when it exceeded the top of the cowpat by approximately $7.6 \mathrm{~cm}$ (3 in.) to prevent accelerated degradation by the presence of vegetation. A pushmower was used to mow areas around the cowpats, and a string trimmer was used on areas adjacent to the cowpats when necessary.

Cowpats were applied to four separate field plots with no history of previous manure application during the spring, summer, fall, and winter seasons (table 1). While many of the sampling periods extended past a single season, each sampling period is referenced by the season in which sample collection began throughout the remainder of the article. The Biological Systems Engineering's weather station (Belfort Instrument) and the local weather station in Blacksburg, Virginia (NOAA, 2006) were used to collect environmental parameters including rainfall, temperature, solar radiation, and relative humidity $(\mathrm{RH})$. Table 1 summarizes sampling dates and weather parameters recorded during the sampling periods.

Samples from cowpats were collected every two to three days for the first seven to ten days following application to the field and then weekly thereafter. More frequent sample collection during the first seven to ten days following application was conducted to ensure observation of any re--

Table 1. Sampling dates and average and high weather variables recorded during the four sampling periods.

\begin{tabular}{|c|c|c|c|c|c|c|c|c|c|}
\hline \multirow[b]{2}{*}{ Season } & \multirow{2}{*}{$\begin{array}{c}\text { Sample } \\
\text { Collection } \\
\text { Dates }\end{array}$} & \multirow{2}{*}{$\begin{array}{c}\text { Sampling } \\
\text { Period } \\
\text { (days) }\end{array}$} & \multirow{2}{*}{$\begin{array}{l}\text { No. of } \\
\text { Sampling } \\
\text { Events }\end{array}$} & \multicolumn{2}{|c|}{$\begin{array}{c}\text { Temperature } \\
\left({ }^{\circ} \mathrm{C}\right)\end{array}$} & \multicolumn{2}{|c|}{$\begin{array}{c}\text { Solar Radiation } \\
(\mathrm{MJ})\end{array}$} & \multirow{2}{*}{$\begin{array}{c}\text { Average } \\
\text { RH } \\
(\%)\end{array}$} & \multirow{2}{*}{$\begin{array}{c}\text { Total } \\
\text { Rainfall } \\
(\mathrm{cm})\end{array}$} \\
\hline & & & & High & Average & High & Average & & \\
\hline Spring & 20 Apr. to 30 Aug. & 133 & 22 & 32.8 & 19.1 & 3.24 & 1.16 & 77.3 & 21.7 \\
\hline Summer & 28 June to 13 Dec. & 175 & 25 & 32.8 & 13.6 & 3.07 & 1.04 & 78.8 & 19.3 \\
\hline Fall & 21 Sept. to 5 Apr. & 196 & 24 & 27.2 & 6.22 & 3.24 & 0.84 & 67.5 & 23.0 \\
\hline Winter & 13 Feb. to 2 July & 135 & 20 & 31.1 & 12.7 & 3.36 & 1.14 & 65.3 & 18.1 \\
\hline
\end{tabular}


growth patterns. Five cowpats were randomly selected for sampling during each sampling event, and manure was collected from both the outer crust and moist interior of the cowpat to obtain a representative sample of the whole cowpat. A sterileware sampling spatula (Bel-Art Products, Pequannock, N.J.) was used to slice the moist cowpats at two points and collect a triangular-shaped sample that included crust material from the top and one side. Attempts were not made to sample the crust of the cowpat separately from the inside material or to obtain equal portions of crust and inner fecal material; therefore, the predicted values are meant to be representative of the bacteria in the cowpat, not the concentrations present in runoff. It should be noted that differences in the moisture content of the crust and interior of the cowpat were dependent on weather conditions, rainfall, and the vegetation surrounding the cowpats. These differences were not monitored, but it was observed that as the cowpat dried out, the entire paddy was often crusty. As the cowpats degraded and became difficult to locate in the field, the moisture content was often similar to that of the surrounding soils. As cowpats began to resemble the surrounding soils, the spatula was used to scrape the remaining fecal material from the soil surface, and differences between the crust and inner fecal material of the cowpat could no longer be distinguished. Cowpats were not re-sampled unless a portion of the cowpat remained intact and appeared undisturbed. Sampling continued until $E$. coli and enterococci concentrations were near or below the detection limit of $10^{2} \mathrm{cfu} \mathrm{g}^{-1}$ wet manure based on the minimum dilutions necessary to achieve enumeration or until cowpats could no longer be located in the field. Preservation of the cowpats in the field was greatly dependent upon the season and corresponding weather conditions. Cowpats applied to the field during the spring were monitored for 133 days, summer cowpats were monitored for 175 days, and fall and winter cowpats were monitored for 196 days and 135 days, respectively (table 1 ).

Cowpat samples were analyzed for $E$. coli and enterococci concentrations. Fecal material was diluted in phosphate buffer solution (Hach Co., Loveland, Colo.) at a 1:10 ratio. Prior to enumeration, all samples were dispersed by treatment with a hand shaker for 10 min (Wrist-Action shaker, Burrell Scientific, Pittsburgh, Pa.), and serial dilutions were performed in $1,000 \mathrm{mg} \mathrm{L}^{-1}$ dilutions of Tween 85 solution. The dispersion treatment improved enumeration by separating particulateattached and bioflocculated cells prior to enumeration. This method was previously developed and validated, and more detail is available in Soupir et al. (2008). E. coli and enterococci concentrations were enumerated on modified mTEC and $\mathrm{mE}$ agar (U.S. EPA, 2000) by membrane filtration (APHA, 1998). Manure moisture content was determined gravimetrically. At least $5 \mathrm{~g}$ of manure were weighted (PG 5002-5 Delta Range, Mettler Toledo, Columbus, Ohio) and then dried (1350 F forced-air oven, VWR Scientific, West Chester, Pa.) at $103^{\circ} \mathrm{C}$ to $105^{\circ} \mathrm{C}$ until equilibrium was reached. Samples were cooled to room temperature in a dessicator and re-weighted. The averages of five cowpats sampled for initial source manure bacterial concentrations and moisture contents are presented in table 2.

Statistical analysis of data was performed using the Statistical Analysis System (SAS, 2004). E. coli and enterococci concentrations in the cowpats over time were normalized by natural log transformation, and linear regression was performed to determine if seasonal bacterial decay would fit a
Table 2. Original source manure properties.

\begin{tabular}{cccc}
\hline Season & $\begin{array}{c}\text { Moisture } \\
\text { Content }(\%)\end{array}$ & $\begin{array}{c}E . \text { coli } \\
\left(\text { cfu g }^{-1} \text { dry wt }\right)\end{array}$ & $\begin{array}{c}\text { Enterococci } \\
\left(\text { cfu g }^{-1} \text { dry wt }\right)\end{array}$ \\
\hline Spring & 82.4 & $4.19 \times 10^{6}$ & $2.54 \times 10^{8}$ \\
Summer & 81.6 & $5.01 \times 10^{6}$ & $7.54 \times 10^{8}$ \\
Fall & 84.8 & $5.06 \times 10^{7}$ & $4.84 \times 10^{6}$ \\
Winter & 85.0 & $9.85 \times 10^{6}$ & $5.88 \times 10^{7}$ \\
\hline
\end{tabular}

first-order approximation. Dummy variables were used to develop a full model representing bacterial decay during all seasons, and an F-test was used to determine differences between first-order decay rates. Differences between initial experimentally determined bacterial concentrations and the statistically determined intercept were also determined by an F-test. Decimal reduction times ( $D$-values), the time required for a 10-fold reduction in population density (Madigan et al., 2000), were calculated from the linear slope of the seasonal die-off curves. $D$-values could be directly implemented into field-scale models to help identify bacterial transport mitigation strategies (Oliver et al., 2006). Higher-order decay models were evaluated and environmental factors were incorporated into the decay models by multiple regression analysis to further improve the coefficient of determination and distribution of residual plots. Season was not included as a covariate because cowpat application dates did not correspond with the beginning date of each season. The beginning of each monitoring period simply falls within that season and in some cases extends well beyond the season (table 1).

Attempts were made to model $E$. coli and enterococci dieoff with two sets of independent variables. Set 1 included average and maximum weather parameters during the time period since the previous sample collection date: time (d), maximum temperature $\left({ }^{\circ} \mathrm{C}\right)$, maximum solar radiation $(\mathrm{MJ})$, average relative humidity $(\%)$, and total rainfall $(\mathrm{cm})$. Set 2 included average and maximum weather variables during the day previous to the sample collection date: time (d), maximum temperature $\left({ }^{\circ} \mathrm{C}\right)$, maximum solar radiation (MJ), average humidity $(\%)$, and total rainfall $(\mathrm{cm})$. The parameters were split into two sets to reduce the potential number of variables in the regression equations and to see if weekly data or daily data were better predictors of bacterial decay. Multiple regression analysis was conducted using the REG procedure in SAS, and the final criteria to be included in the final model were selected based on the $C_{p}$ statistic (Ott and Longnecker, 2001). Five samples were collected during each sampling event, and the number of sampling events is presented in table 1. A few samples were omitted from the regression analysis if a problem occurred during sample processing or enumeration. Therefore, $n$ values of 106 in spring, 121 in summer, 118 in fall, and 93 in winter were used to develop the regression equations. A t-test was used to determine statistically significant slopes and intercepts.

\section{Results AND Discussion}

Initial source bacterial concentrations for $E$. coli and enterococci averaged $1.78 \times 10^{7} \mathrm{cfu} \mathrm{g}^{-1}$ dry manure $(\mathrm{SD}=$ $2.67 \times 10^{7} \mathrm{cfu} \mathrm{g}^{-1}$ dry manure) and $2.97 \times 10^{8} \mathrm{cfu} \mathrm{g}^{-1}$ dry manure $\left(\mathrm{SD}=3.35 \times 10^{8} \mathrm{cfu} \mathrm{g}^{-1}\right.$ dry manure), respectively. $E$. coli concentrations ranged from $1.16 \times 10^{5}$ to $8.63 \times$ $10^{7} \mathrm{cfu} \mathrm{g}^{-1}$ dry manure among the four seasonal studies. Enterococci concentrations in fresh fecal deposits were slightly 

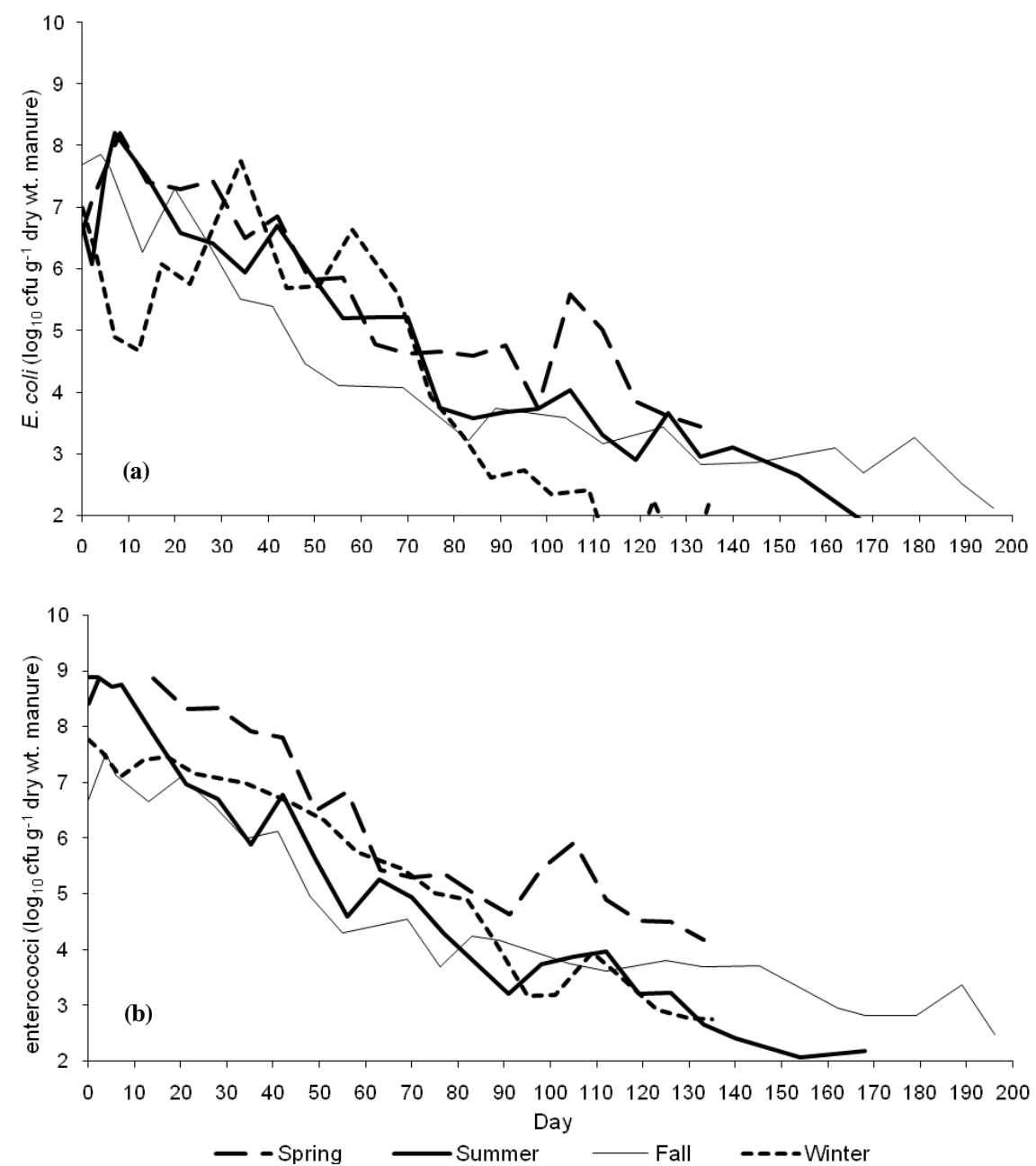

Figure 1. Seasonal die-off patterns of (a) E. coli and (b) enterococci.

higher during spring and summer studies (fig. 1), with summer concentrations being a magnitude of about $100 \times$ greater than fall concentrations (table 2). Previous studies have reported similar bacterial levels in fresh dairy manure and have also noted variability in fecal indicator concentrations among fresh manure samples. Wang et al. (2004) found that $E$. coli concentrations in fresh dairy manure averaged $7.08 \times 10^{6} \mathrm{cfu}$ $\mathrm{g}^{-1}$ dry manure, while Muirhead et al. (2005) reported that $E$. coli concentrations in fresh dairy cow fecal material ranged from $10^{5}$ to $10^{7} \mathrm{~g}^{-1}$ dry manure. Slightly higher initial concentrations of $E$. coli and enterococci observed in this study, compared with the values reported by other investigators, could be partially due to the dispersion treatment (hand shaker for $10 \mathrm{~min}$ followed by serial dilution in Tween-85 $1000 \mathrm{mg} \mathrm{L}^{-1}$ ) used to release cells from organic particulates and disperse bioflocculated cells. Separation of clumped cells through use of a dispersion treatment allows for greater formation of individual colonies during the membrane filtrations procedure, thus resulting in a higher number of colony forming units (cfu).

\section{Seasonal Bacterial Re-Growth and Die-Off Trends}

Cowpats were applied to field plots and monitored for $E$. coli and enterococci concentrations within $24 \mathrm{~h}$ following excretion. Monitoring continued until the lower detection limit of $10^{2} \mathrm{cfu} \mathrm{g}^{-1}$ wet manure was reached or the cowpats had disintegrated to the point that they could no longer be located in the field. Figure 1 presents re-growth and die-off trends for $E$. coli and enterococci in cowpats applied to the field during spring, summer, fall, and winter seasons. Bacterial concentrations in figure 1 are presented on a dry weight basis to remove the impacts of moisture content and rainfall on decay rates.

A fresh fecal cowpat provides an optimal environment (high moisture content, abundance of nutrients) for $E$. coli and enterococci growth and survival, so it was not unexpected when both indicators exhibited re-growth immediately or within the first few days after their land application. Re-growth appeared to vary by both indicator and season. E. coli concentrations peaked at days 7, 7, and 4 during spring, summer, and fall sampling periods, respectively, while enterococci peaked at days 13 and 4 during spring and fall sampling periods, respectively. Re-growth was not observed in enterococci concentrations monitored during the summer sampling period. Mixed results were observed from winter sampling periods, as both indicators exhibited initial die-off. E. coli concentrations experienced about a $100 \times$ decrease following deposition; concentrations increased starting on day 12 , with a peak of $5.73 \times 10^{7} \mathrm{cfu} \mathrm{g}^{-1}$ dry wt occurring on day 34 , followed by a second $100 \times$ decrease and re-growth pattern with a secondary peak of $4.43 \times 10^{6}$ cfu $\mathrm{g}^{-1}$ dry wt (not exceeding initial freshly excreted $E$. coli 
concentrations) on day 58. Enterococci concentrations experienced a slight decrease between days 0 and 7 to $1.29 \times$ $10^{7} \mathrm{cfu} \mathrm{g}^{-1}$ dry wt, followed by re-growth until day 17 to $2.91 \times 10^{7} \mathrm{cfu} \mathrm{g}^{-1}$ dry wt, followed by gradual decay. Regrowth is rarely accounted for in bacterial fate and transport modeling (Benham et al., 2006; Jamieson et al., 2004; Pachepsky et al., 2006; Tian et al., 2002), but it has been frequently observed in laboratory and field studies. Many researchers have observed a re-growth period of just a few days (Conner and Kotrola, 1995; Himathongkham et al., 1999; Thelin and Gifford, 1983; Wang et al., 1996; Wang et al., 2004), but increased concentrations of fecal coliforms in poultry manure applied to bare plots have been observed for up to 12 days (Crane et al., 1980). In situations where heavy rainfall occurs shortly after the application of manure to agricultural lands, the re-growth can influence the concentration of bacteria in runoff.

Cowpats applied to the field in the spring (April) and winter (February) seasons were monitored for the shortest period of time, 133 and 135 days, respectively, while cowpats applied to the field in the fall (September) were monitored for nearly 200 days (table 1 ). During the fall sampling period, the lowest average temperatures $\left(6.22^{\circ} \mathrm{C}\right)$ and solar radiation (0.84 MJ) values were observed. Cool temperatures seemed to preserve both the fecal cowpat in the field and bacterial concentrations, as exhibited by the longer monitoring period. Highest average temperatures $\left(19.1^{\circ} \mathrm{C}\right)$ and average solar radiation values (1.16 $\mathrm{MJ})$ were observed during the spring sampling period, while the maximum solar radiation reading (3.24 MJ) occurred during the winter monitoring season (which continued into July). Quickest decay of the cowpats occurred during warm temperatures when vegetation and insects hastened the disappearance of the fecal deposits.

While collection of all seasonal cowpat samples ceased after a maximum of 200 days, E. coli and enterococci (in levels below the detection limit or in cowpats that could no longer be visually located) were still present in the field and could still contribute loadings to surface waters during runoff events. Kress and Gifford (1984) found that 100-day-old cowpats released fecal coliform concentrations of 4,200 cfu $100 \mathrm{~mL}^{-1}$, and others have concluded that cowpats could remain a source of fecal contamination even long after removal of cattle from grazed pasturelands (Howell et al., 1995; Jawson et al., 1982). End-of-study concentrations of $E$. coli ranged from 81 to $2.8 \times 10^{2} \mathrm{cfu} \mathrm{g}^{-1}$ dry wt manure, and enterococci concentrations ranged from $8.5 \times 10^{2}$ to $8.9 \times 10^{5} \mathrm{cfu}$ $\mathrm{g}^{-1}$ dry wt manure. Therefore, while this study examined fecal bacteria concentrations in cowpats for an extended period of time, it is possible that degraded cowpats or cowpats with bacterial concentrations below the lower detection limit might still remain a source of fecal contamination of surface waters.

\section{First-Order Approximations}

Visual observation of die-off trends over time indicates that first-order decay would not sufficiently estimate bacterial concentrations (fig. 1), but because this approach is commonly used by modelers, the fit of first-order models was examined. The bacterial concentrations during each season were fit as a function of time by linear regression (SAS, 2004) to estimate $E$. coli and enterococci die-off rate constants, and results are presented in table 3 . The die-off rate coefficients, $k$, could be used in equation 1 to predict decay of $E$. coli or
Table 3. E. coli and enterococci seasonal decimal reduction times ( $D$-values) and die-off rate coefficients.

\begin{tabular}{lccccc}
\hline & $\begin{array}{c}D \text {-value } \\
(\text { day })\end{array}$ & $n$ & $\begin{array}{c}k^{[\mathrm{a}]} \\
\left(\text { day }^{-1}\right)\end{array}$ & $\mathrm{R}^{[\mathrm{b}]}$ & $\mathrm{p}^{- \text {value }^{[\mathrm{b}]}}$ \\
\hline E. coli ${ }^{[\mathrm{d}]}$ & & & & & \\
$\quad$ Spring & 33 & 108 & $0.0748 \mathrm{~b}$ & 0.70 & $<0.0001$ \\
Summer & 29 & 123 & $0.0788 \mathrm{~b}$ & 0.84 & $<0.0001$ \\
Fall & 40 & 119 & $0.0581 \mathrm{c}$ & 0.76 & $<0.0001$ \\
$\quad$ Winter & 26 & 104 & $0.0995 \mathrm{a}$ & 0.74 & 0.0799 \\
\hline Enterococci $\left.{ }^{\mathrm{d}]}\right]$ & & & & & \\
$\quad$ Spring & 32 & 107 & $0.0759 \mathrm{a}$ & 0.71 & 0.1745 \\
$\quad$ Summer & 24 & 123 & $0.0978 \mathrm{~b}$ & 0.89 & $<0.0001$ \\
Fall & 41 & 117 & $0.0557 \mathrm{a}$ & 0.81 & 0.0957 \\
$\quad$ Winter & 27 & 105 & $0.0951 \mathrm{~b}$ & 0.90 & 0.4946 \\
\hline
\end{tabular}

[a] Refers to $k$ in equation 1 . For each indicator, $k$-values followed by the same letter do not differ at the 5\% level of significance according to Tukey's pairwise comparison.

[b] P-values $\leq 0.05$ indicate statistically significant differences between initial experimentally determined bacterial concentrations and the statistically determined intercept.

[c] Dry weight basis.

enterococcus. First-order models do not capture re-growth; thus, in some cases, the statistically determined intercept overestimated the experimental initial bacterial concentration in manure during the seasons when re-growth was observed (fig. 1). The implication of this statistical difference is that when initial source manure concentrations, $N_{o}$, are used in equation 1 , the first-order decay models are shifted downward and the time to meet the lower detection limit is reduced. While the observed re-growth period challenges the fit of first-order decay models, the values obtained for the coefficient of determination would lead many to classify the fit of the first-order model as adequate $\left(\mathrm{R}^{2}\right.$ values range from 0.70 to 0.90$)$.

Comparison of $D$-values and die-off rate constants could assist in evaluating the seasonal impacts on E. coli and enterococci decay. The $E$. coli and enterococci $D$-values were very similar, with a 10 -fold reduction in both populations occurring within five days of each other. This indicates that similar on-farm management strategies to reduce indicator populations should apply to both $E$. coli and enterococci. $D$-values were greatest during the fall sampling period for both indicators but lowest during the winter sampling period for $E$. coli and during the summer sampling period for enterococci. While the winter sampling period began during lowtemperature conditions (February), sample collection ceased during the warmest part of the year (July). Die-off rate constants were highest during the winter monitoring period for $E$. coli and during the summer monitoring period for enterococci; however, enterococci decay rates did not differ statistically during the winter and summer monitoring periods. The lowest decay rates occurred during the fall monitoring period for both indicators, but enterococci decay rates were not statistically different between the spring and fall monitoring periods.

Pasture was mowed periodically during the growing season, which likely reduced the bacterial survival time, most likely through its effect on drying rates and increased exposure to solar radiation (Taylor and Burrows, 1971). Van Donsel et al. (1967) found much higher reduction times of indicator organisms when E. coli and Streptococcus faecalis cells were cultured and then poured onto outdoor soil plots. The $90 \%$ reduction times ( $D$-values) varied seasonally, rang- 
ing from 3.3 days in summer to 13.4 days in fall, while the Streptococcus faecalis $90 \%$ reduction times ranged from 2.7 days in summer to 20.1 days in winter (Van Donsel et al., 1967). The protective environment provided by fecal cowpats in this study greatly extended survival of indicator organisms exposed to the external environment when compared to previous studies.

Several researchers have found first-order decay to adequately describe die-off kinetics of fecal indicators from agricultural sources (Crane and Moore, 1986; Himathongkham et al., 1999; Oliver et al., 2006); however, most die-off studies have been conducted under laboratory conditions, making it difficult to compare these laboratory-based findings to the field-based findings presented in this article. In a laboratory investigation, Wang et al. (2004) found that first-order die-off rate coefficients sufficiently described $E$. coli decay in freshly excreted dairy cow manure maintained at three moisture contents and three temperatures, but only after day 3 and for the following 3-week period. Die-off rate coefficients increased as temperature increased, with values averaging $0.11 \mathrm{~d}^{-1}$ at $4^{\circ} \mathrm{C}, 0.20 \mathrm{~d}^{-1}$ at $27^{\circ} \mathrm{C}$, and $0.32 \mathrm{~d}^{-1}$ at $41^{\circ} \mathrm{C}$. E. coli die-off rate coefficients in freshly deposited cattle feces (steers) incubated at $15^{\circ} \mathrm{C}$ averaged $0.054 \mathrm{~d}^{-1}$ (25\% moisture) and $0.058 \mathrm{~d}^{-1}(50 \%$ moisture) over a 111-day sampling period (Oliver et al., 2006). E. coli O157:H7 decay rates were $0.111 \mathrm{~d}^{-1}$ at $4^{\circ} \mathrm{C}(75 \% \mathrm{RH}), 0.046 \mathrm{~d}^{-1}$ at $20^{\circ} \mathrm{C}(50 \% \mathrm{RH})$, and $0.112 \mathrm{~d}^{-1}$ at $37^{\circ} \mathrm{C}(30 \% \mathrm{RH})$ in the top layer of fresh dairy manure and $0.054 \mathrm{~d}^{-1}, 0.074 \mathrm{~d}^{-1}$, and $0.279 \mathrm{~d}^{-1}$ at $4^{\circ} \mathrm{C}, 20^{\circ} \mathrm{C}$, and $37^{\circ} \mathrm{C}$, respectively, in the middle and bottom layers of fresh dairy manure (Himathongkham et al., 1999). In another laboratory investigation, Mubiru et al. (2000) inoculated $E$. coli O157:H7 and nonpathogenic $E$. coli strains in two soil types and enumerated concentrations weekly for an 8-week period. The decay rate constants for a first-order approximation ranged from $0.09 \mathrm{~d}^{-1}$ to $0.17 \mathrm{~d}^{-1}$, varying slightly by strain and soil type, with high regression coefficients ranging from 0.89 to 0.93 . A two-stage first-order function improved the fit, and the initial mortality rate was much higher $\left(0.15 \mathrm{~d}^{-1}\right.$ to $\left.0.25 \mathrm{~d}^{-1}\right)$ than the second stage $\left(0.05 \mathrm{~d}^{-1}\right.$ to $\left.0.08 \mathrm{~d}^{-1}\right)$. Mortality rates of fecal coliforms and fecal streptococci have also been adequately described by a two-stage exponential decay model (Zhai et al., 1995).

$E$. coli die-off rate coefficients developed under laboratory conditions at constant temperatures from freshly excreted dairy manures are generally higher (Wang et al., 2004) than the field-based seasonal die-off rate coefficients presented here. E. coli die-off rate coefficients observed during the fall sampling period are most comparable with results from the Oliver et al. (2006) study conducted on freshly excreted steer feces; however, average temperature conditions of $6.22^{\circ} \mathrm{C}$ (table 1) differ from the $15^{\circ} \mathrm{C}$ incubation temperature in the laboratory study. Mostaghimi et al. (1999) monitored E. coli and fecal coliform concentrations in milker, heifer, and beef cowpats deposited onto grazed pastureland in late April and mid-July and determined seasonal impacts to have a greater influence over bacterial decay than cattle species. If water quality models continue to use first-order decay to predict infield bacterial concentrations, then in-field die-off rate coefficients should be developed for utilization in these models. This study, however, finds that higher-order approximations and inclusion of weather variables more accurately represent in-field bacterial decay.

\section{Multiple Regression AnAlysis to Approximate Seasonal Die-Off Patterns}

Multiple regression analysis was conducted to find the best approximation of die-off in dairy cowpats. Higher-order and two-stage approximations were first examined before addition of weather and moisture parameters to obtain bestfit models. Difficulties in approximating indicator decay rates based on two-stage decay included estimating the breakpoint between the end of re-growth and the beginning of decay. As shown in figure 1, re-growth typically only occurred within the first seven days following excretion except during the winter monitoring period; however, a fit of the regrowth period produced poor regression coefficients $\left(\mathrm{R}^{2}=\right.$ 0.36 for the first stage of $E$. coli in studies beginning in spring, summer, and fall). Because of the difficulties in establishing a breakpoint in two-stage decay models, higher-order approximations were examined. Higher-order approximations excluding weather parameters resulted in increased regression coefficients ( $\mathrm{R}^{2}$ ranging from 0.81 to 0.91 for $E$. coli and $\mathrm{R}^{2}$ ranging from 0.74 to 0.95 for enterococci) and good distribution about zero in residual plots. An F-test was used to examine if statistically significant differences existed between the statistically determined intercept and the initial bacterial concentrations in cowpats produced mixed results. Enterococci initial concentrations did not differ from the intercept ( $\mathrm{p}$-values ranged from 0.1471 to 0.4946 ) except for the spring monitoring period (p-value $=0.008)$, and $E$. coli initial concentrations were statistically different for studies beginning in the fall ( $\mathrm{p}$-value $=0.0090)$ and winter $(\mathrm{p}$-value $=$ $<0.0001)$. While regression coefficients from first-order decay models were deemed reasonable (table 3), examination of residual plots indicated that higher-order approximations and the inclusion of weather data were both necessary to eliminate the trends present in residual plots and improve predictive equations. Figure 2 presents residual plots for $E$. coli during the spring for (a) the first-order decay model and (b) the higher-order approximation model including weather variables.

Crane and Moore (1986) summarized past investigations of bacterial die-off and identified relationships between environmental and physical parameters to bacterial survival as the greatest need for future research. They acknowledged that variability in reported die-off rate coefficients was likely due to the impact of environmental factors on bacterial decay but also concluded that a first-order model accurately described bacterial die-off when considering all conditions. The authors were unsuccessful in correlating environmental parameters and die-off rate coefficients because many environmental factors increase decay only under extreme conditions (non-linear relationships) and oftentimes investigators do not measure certain parameters that might be responsible for variability in die-off rates.

This study monitored a range of environmental parameters in an attempt to more clearly identify which factors are responsible for bacterial decay. Although these parameters are specific to a single field study, they provide information on which weather variables should be considered when modeling decay of bacterial indicators in NPS models. Higherorder approximations including weather variables are presented in table 4, and figure 3 presents an example of the predicted and observed $E$. coli and enterococci decay during the fall season. Predicted values were calculated using the equations presented in table 4 for $E$. coli and enterococci 

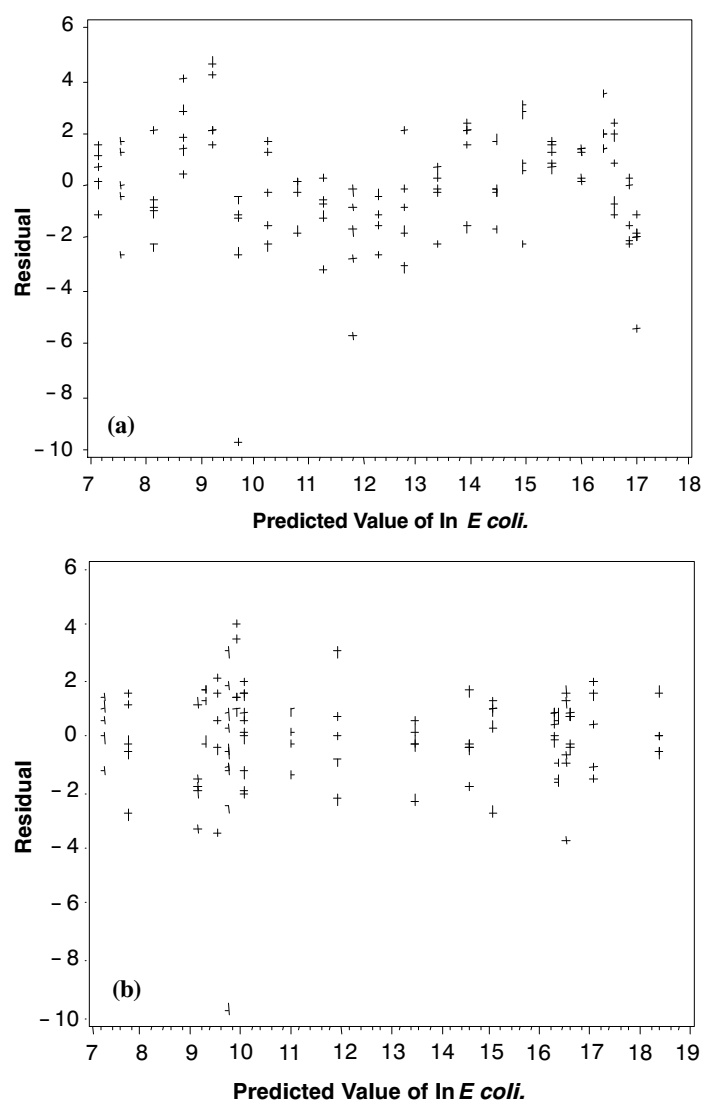

Figure 2. Residual plots for $E$. coli during the spring season for (a) firstorder decay and (b) higher-order approximations combined with weather variables. decay beginning during the fall monitoring period. All four weather parameters significantly improved predictions of $E$. coli and enterococci decay by increasing regression coefficients and distribution about zero of residual plots during at least one season for each indicator. The impact of temperature on bacterial decay has been previously well documented, and solar radiation has also been identified as an important factor associated with bacterial decay (Crane et al., 1983; Taylor and Burrows, 1971). Inclusion of weather parameters improved either the regression coefficient or residual plot distribution in all models except for the $E$. coli and enterococci die-off during studies beginning in the fall. It is likely that cooler temperatures and lower solar radiation recorded during the fall and winter months were not extreme enough to contribute significantly to bacterial decay.

The impact of moisture content on the die-off of $E$. coli and enterococcus is unclear in the literature. Some studies have found that low moisture content will promote die-off (Entry et al., 2000; Sjogren, 1994; Wang et al., 2004), while others have found little or no effect (Oliver et al., 2006; Ritchie et al., 2003; Vinten et al., 2002). In this study, moisture content of the manure was not included in the dry-weight-based decay models because it is a parameter necessary to calculate bacterial concentrations in dry-weight manures. However, at least one of the two factors impacting moisture content, i.e., rainfall and relative humidity, were included as a statistically significant model parameter in most of the presented models, indirectly indicating that moisture is a factor in bacterial decay. Moisture content was included as a variable in separately developed wet-based manure die-off models (Soupir, unpublished data) and was identified as a significant parameter for inclusion in E. coli spring, summer, and fall models ( $\mathrm{p}$-value $=0.0173$ ) and enterococci spring, summer,

Table 4. Best estimates of seasonal $E$. coli and enterococci die-off by higher-order approximation and including weather parameters. ${ }^{[a]}$

Seasonal Die-off Models: E. coli

\begin{tabular}{|c|c|c|c|c|c|c|c|c|c|c|c|}
\hline \multicolumn{3}{|c|}{$\begin{array}{l}\text { In E. coli (dry wt) die-off: } \\
\text { Spring }\left(\mathrm{R}^{2}=0.7941\right)\end{array}$} & \multicolumn{3}{|c|}{$\begin{array}{c}\text { In } E \text {. coli }(\text { dry wt) die-off: } \\
\text { Summer }\left(\mathrm{R}^{2}=0.8821\right)\end{array}$} & \multicolumn{3}{|c|}{$\begin{array}{l}\text { In E. coli (dry wt) die-off: } \\
\text { Fall }\left(\mathrm{R}^{2}=0.9125\right)\end{array}$} & \multicolumn{3}{|c|}{$\begin{array}{l}\ln E \text {. coli (dry wt) die-off: } \\
\text { Winter }\left(\mathrm{R}^{2}=0.8213\right)\end{array}$} \\
\hline & Parameter & & & Parameter & & & Parameter & & & Parameter & \\
\hline Variable & Estimate & $\mathrm{p}$-value & Variable & Estimate & p-value & Variable & Estimate & p-value & Variable & Estimate & $\mathrm{p}$-value \\
\hline Intercept & 7.269 & 0.0400 & Intercept & 10.57 & 0.0004 & Intercept & 18.22 & $<0.0001$ & Intercept & 18.19 & $<0.0001$ \\
\hline Time & 0.2502 & 0.0098 & Time & -0.1066 & $<0.0001$ & Time & -0.2226 & $<0.0001$ & Time & 0.4381 & 0.0015 \\
\hline Time $^{2}$ & $-1.201 \times 10^{-2}$ & 0.0003 & Time $^{2}$ & $2.896 \times 10^{-4}$ & 0.0046 & Time $^{2}$ & $1.53 \times 10^{-3}$ & $<0.0001$ & Time $^{2}$ & $-6.97 \times 10^{-3}$ & $<0.0001$ \\
\hline Time $^{3}$ & $1.324 \times 10^{-4}$ & 0.0004 & Temp PWH & 0.3842 & $<0.0001$ & Time $^{3}$ & $-3.72 \times 10^{-6}$ & $<0.0001$ & Time $^{3}$ & $2.792 \times 10^{-5}$ & $<0.0001$ \\
\hline Time $^{4}$ & $-4.567 \times 10^{-7}$ & 0.0008 & RH PWA & $-6.925 \times 10^{-2}$ & 0.0506 & & & & Temp PWH & -0.1881 & 0.0055 \\
\hline Temp PWH & 0.1839 & 0.0365 & Rain PWT & 0.4536 & 0.0007 & & & & SR PWH & -3.493 & 0.1105 \\
\hline RH PWA & $6.181 \times 10^{-2}$ & 0.0470 & & & & & & & Rain PWT & 0.3509 & 0.0094 \\
\hline Rain PWT & $-8.893 \times 10^{-2}$ & 0.0488 & & & & & & & & & \\
\hline
\end{tabular}

Seasonal Die-off Models: Enterococci

\begin{tabular}{|c|c|c|c|c|c|c|c|c|c|c|c|}
\hline \multicolumn{3}{|c|}{$\begin{array}{l}\text { In enterococci (dry wt) die-off: } \\
\text { Spring }\left(\mathrm{R}^{2}=0.8159\right)\end{array}$} & \multicolumn{3}{|c|}{$\begin{array}{l}\text { In enterococci (dry wt) die-off: } \\
\text { Summer }\left(R^{2}=0.9644\right)\end{array}$} & \multicolumn{3}{|c|}{$\begin{array}{c}\text { In enterococci (dry wt) die-off: } \\
\text { Fall }\left(\mathrm{R}^{2}=0.8960\right)\end{array}$} & \multicolumn{3}{|c|}{$\begin{array}{l}\text { In enterococci (dry wt) die-off: } \\
\text { Winter }\left(R^{2}=0.9062\right)\end{array}$} \\
\hline & Parameter & & & Parameter & & & Parameter & & & Parameter & \\
\hline Variable & Estimate & p-value & Variable & Estimate & p-value & Variable & Estimate & $\mathrm{p}$-value & Variable & Estimate & $\mathrm{p}$-value \\
\hline Intercept & 25.48 & $<0.0001$ & Intercept & 20.40 & $<0.0001$ & Intercept & 16.713 & $<0.0001$ & Intercept & 17.79 & $<0.0001$ \\
\hline Time & 0.371 & $<0.0001$ & Time & -0.3139 & $<0.0001$ & Time & -0.0605 & 0.0674 & Time & $-9.566 \times 10^{-2}$ & $<0.0001$ \\
\hline Time $^{2}$ & $-1.359 \times 10^{-2}$ & $<0.0001$ & Time $^{2}$ & $2.88 \times 10^{-3}$ & $<0.0001$ & Time $^{2}$ & $-1.46 \times 10^{-3}$ & 0.0456 & Rain PDT & 0.1615 & 0.0577 \\
\hline Time $^{3}$ & $1.471 \times 10^{-4}$ & $<0.0001$ & Time $^{3}$ & $-1.017 \times 10^{-5}$ & $<0.0001$ & Time $^{3}$ & $1.692 \times 10^{-5}$ & 0.0037 & & & \\
\hline Time $^{4}$ & $-5.147 \times 10^{-7}$ & $<0.0001$ & Temp PDH & 0.1283 & 0.0011 & Time $^{4}$ & $-4.809 \times 10^{-8}$ & 0.0013 & & & \\
\hline RH PWA & -0.1361 & $<0.0001$ & SR PDA & -0.9569 & $<0.0001$ & & & & & & \\
\hline
\end{tabular}

[a] $\mathrm{RH}=$ relative humidity, $\mathrm{SR}=$ solar radiation, $\mathrm{PWA}=$ previous week average, $\mathrm{PWH}=$ previous week high, $\mathrm{PWT}=$ previous weekly total, $\mathrm{PDA}=$ previous day average, $\mathrm{PDH}=$ previous day high, and $\mathrm{PDT}=$ previous day total. 


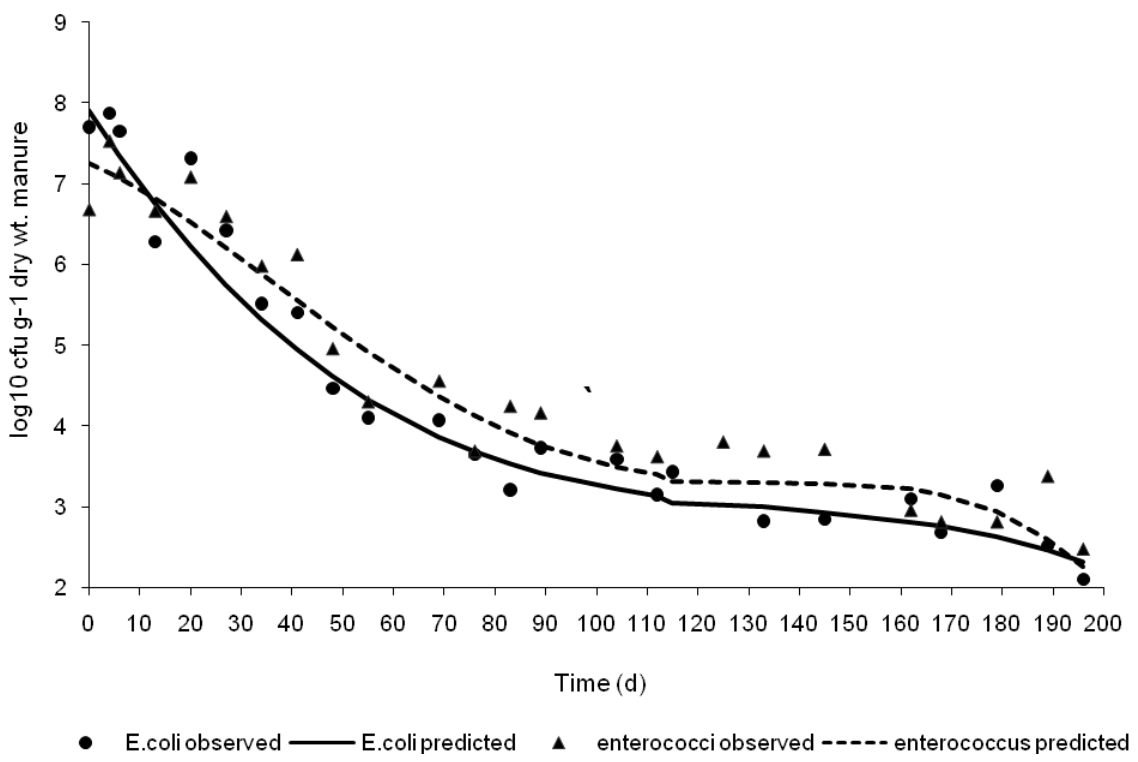

Figure 3. Example of predicted and observed $E$. coli and enterococcus decay. Predicted values are calculated using the equations presented in table 4 for $E$. coli and enterococci decay beginning during the fall monitoring period.

fall, and winter models (p-value $=0.0026)$. Kress and Gifford (1984) reported that declines in peak fecal coliform counts occurred after a second rainfall simulation, suggesting that bacteria available for transport were washed from the feces during the first simulation. While this study sampled the entire cowpat, it is likely that the decrease in fecal indicators present in the surface crust of the cowpat following rainfall events was reflected in the total bacterial count.

This research successfully presents a different analysis to capture the re-growth and die-off dynamics of $E$. coli and enterococci over an extended period of time. While a fieldbased study makes it difficult to assess the direct impact of individual environmental factors on bacterial decay, inclusion of weather parameters consistently improved predictive capabilities of bacterial decay models during all monitoring periods except fall, which covered the period of September to April. Moisture also indirectly seemed to impact bacterial decay through the inclusion of relative humidity or rainfall in most models. Clearly, higher-order approximations and the inclusion of weather variables improve predictions of bacterial decay when compared to first-order approximations; however, caution is advised prior to direct implementation of these procedures into NPS models unless similar field conditions are being simulated. Cowpats examined in this study were undisturbed, and rotational or continuous grazing systems will often allow for repeated grazing and thus trampling of the cowpats before previous deposits disappear, likely increasing decay rates through environmental exposure. Additional field-based monitoring of bacterial decay and weather parameters is necessary to represent the many different fecal sources present within a watershed and to further monitor the impacts of seasonal and weather parameters over time.

\section{Summary ANd CONClusions}

Standard cowpats were formed and applied to pastureland during spring, summer, fall, and winter seasons to assess $E$. coli and enterococci re-growth and decay patterns. Firstorder approximations were used to determine die-off rate co- efficients and decimal reduction times ( $D$-values). Seasonal variations in decay patterns were assessed. Higher-order approximations and weather parameters were evaluated by multiple regression analysis to identify environmental parameters impacting in-field $E$. coli and enterococci decay.

Populations of $E$. coli and enterococci both exhibited regrowth, which seemed to differ by both indicator and season, immediately or within the first few days after field application. Die-off rate constants were greatest in cowpats applied to pasture during late winter and monitored into summer months for E. coli $\left(k=0.0995 \mathrm{~d}^{-1}\right)$ and applied to the field during the summer and monitored until December for enterococci $\left(k=0.0978 \mathrm{~d}^{-1}\right)$. Decay rates were lowest in cowpats applied to the pasture during the fall and monitored over the winter $\left(k=0.0581 \mathrm{~d}^{-1}\right.$ for $E$. coli and $k=0.0557 \mathrm{~d}^{-1}$ for enterococci). In general, cool temperatures preserved bacterial concentrations, while increased decay occurred during warm temperatures when vegetation and insects hastened the disappearance of the fecal deposits. First-order kinetics approximated $E$. coli and enterococci decay rates with regression coefficients ranging from 0.70 to 0.90 ; however, when indicators exhibited re-growth patterns, the first-order approximations overestimated initial concentrations present in freshly excreted manures. $E$. coli and enterococci $D$-values were very similar, with a 10 -fold reduction in both populations occurring within five days of each other. The $D$-values were greatest during the fall monitoring period (40 and 41 days for $E$. coli and enterococci, respectively).

Higher-order approximations and addition of weather variables improved regression coefficients to values ranging from 0.79 to 0.96 , and improved distribution of residual plots for both indicators was noted. The addition of weather variables improved predictability of regression equations for all seasonal studies except the fall monitoring period. It is possible that the weather conditions that occurred during the fall monitoring period were not extreme enough to contribute significantly to bacterial decay. Statistically significant variables included in the models predicting bacterial decay during the spring, summer, and winter monitoring periods were temperature, solar radiation, rainfall, and relative humidity. 
Die-off rate coefficients previously reported in the literature are generally higher than the field-based seasonal die-off rate coefficients presented here. New die-off rate coefficients should be developed in the field for implementation in decay models if first-order decay models continue to be used to predict in-field bacterial concentrations. Comparable $E$. coli and enterococci seasonal $D$-values suggest that similar on-farm management strategies should reduce both $E$. coli and enterococci indicator populations. The use of higher-order approximations and the inclusion of weather variables to better capture re-growth and die-off trends over extended periods of time improved predictions of in-field bacterial decay. It is not recommended that the equations developed in this study be directly implemented into NPS models for all fecal sources. The need has been identified for improved techniques to model fecal bacteria die-off, and this approach could be used to develop similar equations for other fecal sources and land uses.

\section{ACKNOWLEDGEMENTS}

The authors would like to thank Marissa Duff, Whitney Thomas, Kelsey Ross, and Henry Lehmann for assistance with sample collection and analysis. This work is partially supported by the USDA Cooperative State Research, Education, and Extension Service (CSREES) Food and Agricultural Sciences National Needs Graduate Fellowship Grants Program, the Waste Policy Institute Graduate Fellowship Program at Virginia Tech, Virginia Tech Graduate School, National Science Foundation ADVANCE Grant No. SBE-0244916, and EPA STAR Fellowship No. 91677501-0.

\section{REFERENCES}

APHA. 1998. Standard Methods for the Examination of Water and Wastewater. 20th ed. L. S. Clesceri, A. E. Greenburg, and A. D. Eaton, eds. Washington, D.C.: American Public Health Association, American Water Works Association, and Water Environment Federation.

ASM. 2002. Manual of Environmental Microbiology. 2nd ed. C. J. Hurst, R. L. Crawford, G. R. Knudsen, M. J. McInerney, and L. D. Stetzenbach. Washington, D.C.: American Society for Microbiology.

Benham, B. L., C. Baffaut, R. W. Zeckoski, K. R. Mankin, Y. A. Pachepsky, A. A. Sadeghi, K. M. Brannan, M. L. Soupir, and M. J. Habersack. 2006. Modeling bacteria fate and transport in watersheds to support TMDLs. Trans. ASABE 49(4): 987-1002.

Conner, D. E., and J. S. Kotrola. 1995. Growth and survival of Escherichia coli O157:H7 under acidic conditions. Appl. Environ. Microbiol. 61(1): 382-385.

Crane, S. R., and J. A. Moore. 1986. Modeling enteric bacterial die-off: A review. Water Air Soil Poll. 27(3/4): 411-439.

Crane, S. R., P. W. Westerman, and M. R. Overcash. 1980. Die-off of fecal indicator organisms following land application of poultry manure. J. Environ. Qual. 9(3): 531-537.

Crane, S. R., J. A. Moore, M. E. Grismer, and J. R. Miner. 1983. Bacterial pollution from agricultural sources: A review. Trans. ASAE 26(3): 858-866.

DeGuise, K. A., M. L. Wolfe, and T. A. DillahaIII. 1999. A foundation for modeling bacterial contamination of surface waters due to nonpoint sources. ASAE Paper No. 992153. St. Joseph, Mich.: ASAE.

Doran, J. W., and D. M. Linn. 1979. Bacteriological quality of runoff water from pastureland. Appl. Environ. Microbiol. 37(5): 985-991.
Doran, J. W., J. S. Schepers, and N. P. Swanson. 1981. Chemical and bacteriological quality of pasture runoff. J. Soil Water Conserv. 36(3): 166-171.

Ellis, J. R., and T. M. McCalla. 1978. Fate of pathogens in soils receiving animal wastes: A review. Trans. ASAE 21(2): 309-313.

Entry, J. A., R. K. Hubbard, J. E. Thies, and J. J. Fuhrmann. 2000. The influence of vegetation in riparian filterstrips on coliform bacteria: I. Movement and survival in water. J. Environ. Qual. 29(4): 1206-1214.

Himathongkham, S., S. Bahari, H. Riemann, and D. Cliver. 1999. Survival of Escherichia coli $\mathrm{O} 157: \mathrm{H} 7$ and Salmonella typhimurium in cow manure and cow manure slurry. FEMS Microbiol. Lett. 178(2): 251-257.

Howell, J. M., M. S. Coyne, and P. Cornelius. 1995. Fecal bacteria in agricultural waters of the bluegrass region of Kentucky. $J$. Environ. Qual. 24(3): 411-419.

Jamieson, R. C., R. J. Gordon, D. Joy, and H. Lee. 2004. Assessing microbial pollution of rural surface waters: A review of current watershed-scale modeling approaches. Agric. Water Mgmt. 70(1): 1-17.

Jawson, M. D., L. F. Elliott, K. E. Saxton, and D. H. Fortier. 1982. The effect of cattle grazing on indicator bacteria in runoff from a Pacific Northwest watershed. J. Environ. Qual. 11(4): 621-627.

Kress, M., and G. F. Gifford. 1984. Fecal coliform release from cattle fecal deposits. Water Resour. Bull. 2(1): 61-66.

Kudva, I. T., K. Blanch, and C. J. Hovde. 1998. Analysis of Escherichia coli $0157: \mathrm{H} 7$ survival in ovine or bovine manure and manure slurry. Appl. Environ. Microbiol. 64(9): 3166-3174.

Madigan, M. T., J. M. Martinko, and J. Parker. 2000. Brock Biology of Microorganisms. 9th. Upper Saddle River, N.J.: Prentice-Hall.

Mancini, J. L. 1978. Numerical estimates of fecal coliform mortality rates under various conditions. J. Water Pollut. Control Fed. 51(1): 13-19.

Moore, J. A., M. E. Grismer, S. R. Crane, and J. R. Miner. 1982. Evaluating dairy waste management systems' influence on coliform concentration in runoff. Station Bulletin 658. Corvallis, Ore.: Oregon State University, Agricultural Experiment Station.

Moore, J. A., J. Smyth, S. Baker, and J. R. Miner. 1988. Evaluating coliform concentrations in runoff from various animal waste management systems. Special Report 817. Corvallis, Ore.: Oregon State University, Agricultural Experiment Station.

Mostaghimi, S., K. De Guise, and P. W. McClellan. 1999. Field investigation of bacteria die-off rates in cow manure and poultry litter. Report No. 0301BAC, Richmond, Va.: Virginia Department of Conservation and Recreation.

Mubiru, D. N., M. S. Coyne, and J. H. Grove. 2000. Mortality of Escherichia coli $\mathrm{O} 157: \mathrm{H} 7$ in two soils with different physical and chemical properties. J. Environ. Qual. 29(6): 1821-1825.

Muirhead, R. W., R. P. Collins, and P. J. Bremer. 2005. Erosion and subsequent transport state of Escherichia coli from cowpats. Appl. Environ. Microbiol. 71(6): 2875-2879.

NOAA. 2006. Daily climate data for Blacksburg, Danville, Lynchburg and Roanoke, VA, and Bluefield, WV. Bohemia, N.Y.: National Weather Service, Eastern Region Headquarters. Available at: www.erh.noaa.gov/rnk/climate/f6/html/F6.html. Accessed 16 August 2007.

Oliver, D. M., P. M. Haygarth, C. D. Clegg, and L. Heathwaite. 2006. Differential $E$. coli die-off patterns associated with agricultural matrices. Environ. Sci. Tech. 40(18): 5710-5716.

Ott, R. L., and M. Longnecker. 2001. Statistical Methods and Data Analysis. 5th ed. Pacific Grove, Cal.: Wadsworth Group.

Pachepsky, Y. A., A. M. Sadeghi, S. A. Bradford, D. R. Shelton, A. K. Guber, and T. Dao. 2006. Transport and fate of manure-borne pathogens: Modeling perspective. Agric. Water Mgmt. 86(1-2): 81-92.

Ritchie, J. M., G. R. Campbell, J. Shepherd, Y. Beaton, D. Jones, K. Killham, and R. R. E. Artz. 2003. A stable bioluminescent construct of Escherichia coli O157:H7 for hazard assessments of 
long-term survival in the environment. Appl. Environ. Microbiol. 69(6): 3359-3367.

SAS. 2004. SAS Version 9.1. Cary, N.C.: SAS Institute, Inc.

Sjogren, R. E. 1994. Prolonged survival of an environmental Escherichia coli in laboratory soil microcosms. Water Air Soil Poll. 75(3-4): 389-403.

Soupir, M. L., S. Mostaghimi, E. R. Yagow, C. Hagedorn, and D. H. Vaughan. 2006. Transport of fecal bacteria from poultry litter and cattle manures applied to pastureland. Water Air Soil Poll. 169(1-4): 125-136.

Soupir, M. L., S. Mostaghimi, and N. L. Love. 2008. Method to partition between attached and unattached $E$. coli in runoff from agricultural lands. J. American Water Resour. 45(1): DOI: 10.1111 / j.1752-1688.2008.00264.x.

Taylor, R. J., and M. R. Burrows. 1971. The survival of Escherichia coli and Salmonella dublin in slurry on pasture and the infectivity of Salmonella dublin for grazing calves. British Vet. J. 127(11): 536-543.

Thelin, R., and G. F. Gifford. 1983. Fecal coliform release patterns from fecal material of cattle. J. Environ. Qual. 12(1): 57-63.

Tian, Y. Q., P. Gong, J. D. Radke, and J. Scarborough. 2002. Spatial and temporal modeling of microbial contaminants on grazing farmlands. J. Environ. Qual. 31(3): 860-869.

U.S. EPA. 1986. Ambient water quality criteria for bacteria. EPA-440-5-84-002. Washington, D.C.: U.S. EPA, Office of Water.

U.S. EPA. 1998. Bacterial water quality standards for recreational waters (freshwater and marine waters). Washington, D.C.: U.S. EPA, Office of Water.
U.S. EPA. 2000. Improved enumeration methods for the recreational water quality indicators: Enterococci and Escherichia coli. EPA-821-R-97-004. Washington, D.C.: U.S. EPA, Office of Science and Technology.

U.S. EPA. 2002. Implementation guidance for ambient water quality criteria for bacteria. EPA-823-B-02-003. Washington, D.C.: U.S. EPA, Office of Water.

U.S. EPA. 2003. National pollutant discharge elimination system permit regulation and effluent limitation guidelines and standards for concentrated animal feeding operations (CAFOs): Final rule. Federal Register 68(29): 7176-7274.

Van Donsel, D. J., E. E. Geldreich, and N. A. Clarke. 1967. Seasonal variations in survival of indicator bacteria in soil and their contribution to storm-water pollution. Appl. Microbiol. 15(6): 1362-1370.

Vinten, A. J. A., D. R. Lewis, D. R. Fenlon, K. A. Leach, R. Howard, I. Svoboda, and I. Ogden. 2002. Fate of Escherichia coli and Escherichia coli $\mathrm{O} 157$ in soils and drainage water following cattle slurry application at three sites in southern Scotland. Soil Use Mgmt. 18(3): 223-231.

Wang, G. D., T. Zhao, and M. P. Doyle. 1996. Fate of enterohemorrhagic Escherichia coli O157:H7 in bovine feces. Appl. Environ. Microbiol. 62(7): 2567-2570.

Wang, L., K. R. Mankin, and G. L. Marchin. 2004. Survival of fecal bacteria in dairy cow manure. Trans. ASAE 47(4): 1239-1246.

Zhai, Q., M. S. Coyne, and R. I. Barnhisel. 1995. Mortality rates of fecal bacteria in subsoil amended with poultry manure. Bioresource Tech. 54(2): 165-169. 